\title{
ALUNO-AUTOR: A APRENDIZAGEM DA ESCRITA LITERÁRIA NAS SÉRIES INICIAIS DO ENSINO FUNDAMENTAL
}

Elisa Maria Dalla-Bona* Leilah Santiago Bufrem**

RESUMO: Pesquisa etnográfica sobre a escrita do texto literário realizada numa turma de $4^{\circ}$ ano do ensino fundamental municipal de Curitiba. O estudo parte do conceito de aluno-autor, criado por Catherine Tauveron para sustentar o argumento de que a escola pode desenvolver nas crianças pequenas uma postura de autor. $\mathrm{O}$ artigo analisa dois textos produzidos por alunos, sendo um deles uma narrativa, e o outro, uma fábula. Paralelamente, apresenta as estratégias adotadas pelo professor para familiarizar os alunos com as características dos gêneros literários, como forma de nortear a sua escrita, de modo a contemplarem em seus textos os elementos da arquitetura desses gêneros, como tema, intriga, narrador, ponto de vista, personagem, estrutura, sequência, coerência, verossimilhança, espaço e tempo. Enfatiza, ainda, o papel do professor como responsável por instigar a reflexão dos alunos sobre sua escrita e criar as condições pedagógicas para que escrevam com prazer, autonomia e criatividade.

Palavras-chave: Escrita Literária; Letramento Literário; Ensino Fundamental.

\section{STUDENT-AUTHOR: LEARNING LITERARY WRITING IN THE EARLY GRADES OF ELEMENTARY SCHOOL}

ABSTRACT: This is an ethnographic research on literary text writing carried out with a $4^{\text {th }}$ grade class of a municipal elementary school in Curitiba, Brazil. The study is based on Catherine Tauveron's concept of student-author, which supports that schools can induce the development of author's attitude in small children. The paper analyzes two texts prepared by students: a narrative and a fable. It also presents the strategies used by the teacher to familiarize students with the characteristics of literary genres, as a means to organize their writing, so that they include elements of the common architecture of genres in their texts, such as theme, intrigue, narrator, point of view, character, structure, sequence, coherence, verisimilitude, space and time. It also emphasizes the role of teachers as responsible for enticing students to think about their writing and creating the pedagogic conditions so students write with pleasure, autonomy and creativity.

Keywords: Literary Writing; Literary Literacy; Elementary School.

\footnotetext{
*Pedagoga; Mestre e Doutora em Educação; Professora do Curso de Pedagogia da Universidade Federal do Paraná (UFPR); em 2010, realizou estágio no Institut National de Recherche Pédagogique, em Lyon (França). E-mail: elisabona2@gmail.com

** Mestre em Educação, Doutora em Ciência da Informação, com pós-doutorado na Universidad Autónoma de Madrid, Professora do Programa de Pós-Graduação em Educação pela Universidade Federal do Paraná (UFPR), Pesquisadora do CNPq. E-mail: santiagobufrem@gmail.com
} 


\section{INTRODUCุÃO}

Para chegar às reflexões relativas à escrita literária nas séries iniciais do ensino fundamental é preciso inicialmente considerar alguns conceitos relativos à escrita, à leitura, às especificidades do texto literário e ao papel do leitor. As teorias que apoiaram as discussões sobre a leitura literária na escola, até os anos de 1970, se caracterizaram pela prioridade dada ao texto. Foi somente a partir do final daquela década que as teorias passaram a dar prioridade ao processo da leitura. Diferentes trabalhos, como os de Jauss e Iser, expoentes da estética da recepção e fundadores da Escola de Constance, na Alemanha, e os dos franceses Riffaterre, Renier, Eco, Gervais e Picard, entre outros, passam a defender que a fonte de produção de sentido não reside somente no texto, mas também, e talvez primeiramente, no receptor, no sujeito leitor. Segundo essa concepção, o texto é um produto inacabado, uma mensagem puramente virtual, nada mais do que um conjunto de indeterminações, de aberturas de sentidos, que somente a colaboração ativa de um leitor pode transformar em um sistema ordenado de significações. Ler é um ato interativo entre o texto e o leitor, e o sentido de um texto literário é algo a ser construído pelo leitor. Todo ato de leitura envolve dialogismo, a interação entre o objeto artístico e seu leitor.

O texto literário, portanto, não é um sistema de sinais fechado sobre si mesmo, mas, ao contrário, é plural, aberto e só pode ser compreendido a partir da sua relação com a realidade, ou com os textos anteriores da literatura, do inconsciente e da sociedade. No processo da leitura, são considerados igualmente tanto o texto quanto o leitor.

Dufais, Gemenne e Ledur (2005) ${ }^{1}$ afirmam que, de um lado, é preciso admitir que a leitura é um processo de construção que repousa sobre as competências e as motivações do leitor, que o leitor não é submisso ao filtro dessa leitura-construção e que o texto não é apenas um artefato desprovido de toda significação, pois é situado num dado contexto sociocultural. Assim, a leitura está longe de ser uma simples decodificação de um sentido preexistente; ao contrário, ela é um processo dialético em que a liberdade e a coerção se misturam de maneira indissociável.

Quanto à literatura, ela não é concebida como objeto ou como produto acabado, mas o que ela é como projeto ou representação na mente do leitor, a quem cabe conferir valor ao texto. Valoriza-se a recepção do 
texto literário, e, nesse processo, o receptor/leitor recorre às suas emoções, imaginação e subjetividade para explorar as virtualidades do texto (a polissemia, a subversão, a ficcionalidade, a transgressão e a poeticidade). $\mathrm{O}$ que caracteriza um texto como literário, segundo Dufais, Gemenne e Ledur (2005), é o seu ritmo, sua verossimilhança, sua força persuasiva e seu valor estético, sendo que a literatura, antes de ser um corpus de obras ou tipos de textos, é uma maneira de ler. A leitura literária exerce uma função social indireta, porque ela não produz somente um novo texto, mas também um novo leitor e um novo cidadão, capaz de ver o mundo com outros olhos.

Partindo dessas afirmações e relacionando-as à escrita literária, uma das primeiras particularidades a considerar é que um texto literário precisa ser concebido tendo em vista o seu potencial leitor.

Como o leitor será um parceiro ativo na construção do texto literário, cabe ao autor, segundo Tauveron e Seve (2005), programar uma parte das suas reações, orientar ou desorientar as suas hipóteses, ocasionalmente exercer sobre ele sua astúcia e permitir áreas de exploração livre e de lugares para iluminar. São essas questões que devem orientar o professor que pretende ensinar seus alunos iniciantes na escrita literária, que será analisada neste artigo.

Embora essas questões venham sendo discutidas e concepções teóricas consistentes se façam presentes na literatura sobre o tema em nosso país, o trabalho com a escrita literária na escola tem sido muito criticado. Poslaniec (2002a, b) afirma que, em geral, as crianças são obrigadas a escrever literatura, mas os textos literários produzidos na escola não passam de estereótipos, pois não são dados aos alunos as condições, as ferramentas ou os saberes de referência. Neste artigo, procuraremos, a partir de situações reais vividas em uma sala de aula, refletir sobre as condições e os conhecimentos a que os alunos têm acesso, de forma a explorarmos as alternativas para o ensino da escrita literária na escola.

\section{ALUNO-AUTOR}

A expressão aluno-autor foi criada pela pesquisadora francesa Catherine Tauveron, que, em suas publicações, afirma ser possível estabelecer nas séries iniciais as condições para desenvolver nos alunos a confiança de 
que podem ser autores e de que podem escrever textos literários. A autora afirma (TAUVERON, 1996, p. 191) que a escola não tem por vocação formar escritores, mas tampouco pode impedir que as vocações se revelem. Mais precisamente, a escola não pode impedir as crianças de explorar ao seu nível os poderes da escrita e de testar as potencialidades estéticas e mais geralmente subversivas de sua língua. No início do período escolar, a criança ainda tem um longo caminho a percorrer para alcançar o domínio da língua e do discurso, mas, ao mesmo tempo, ela pode ser estimulada a se reconhecer como um autor e desenvolver um trabalho textual com uma intenção artística, visando um efeito sobre o leitor.

Vários autores (LECUYER, 1992; TAUVERON, 1996; DESVIGNES, 2000) criticam a ideia de que escrever literatura é um dom, afirmando que se trata de uma habilidade que a escola pode desenvolver nas crianças.

A transformação do aluno depende, segundo Gonzáles (2009), de algumas condições indispensáveis:

- Ler como um autor. Espera-se que o autor conheça a fundo as obras com as quais seu trabalho tem relação, para tomar consciência do funcionamento do gênero como uma "máquina" expressiva da qual ele precisa descobrir os mecanismos;

- Tomar decisões como autor, se situando no contexto de um gênero. A elaboração do plano da história é um dos momentos-chave para a aprendizagem da postura de autor. A partir desse plano, o aluno pode ser guiado pelas possibilidades do gênero literário escolhido e assumir de maneira criativa o papel de narrador;

- Dialogar com outros autores. A classe é uma comunidade de autores, interlocutores e parceiros à disposição do aluno-autor para testar os efeitos do seu texto;

- Escrever para os leitores. Os alunos devem levar em consideração o seu destinatário, pois um autor se constrói porque ele procura seu leitor.

Em resumo, o que Gonzáles (2009, p. 205) propõe é utilizar estratégias de autor em situação escolar, de forma que o aluno se coloque na pele do autor e vivencie atividades que impliquem assumir certas responsabilidades, ou certa postura.

Para Gromer e Scheidhauer (1996), a criança deve poder jogar com a linguagem, descobrindo os processos e seus efeitos; ela deve poder experimentá-los em si e sobre os outros. Por isso é preciso que ela tenha implícita ou explicitamente analisado os jogos literários e que eles tenham 
regras claras. Somente a partir dessas condições ela poderá tentar suas próprias combinações e produzir um escrito original. O começo de tudo é a leitura. O resultado final do jogo é um escrito governado por suas próprias leis, que retorna a seu autor, a sua vida, a suas emoções por vias frequentemente inconscientes. É um escrito que se busca através de tentativas e de retomadas, mas que sempre espera tocar o outro que o lê, espera se aproximar do leitor e ser compreendido (GROMER; SCHEIDHAUER, 1996, p. 31). Assim, o texto da criança vai adquirindo a forma de literário na medida em que se torna fruto de um jogo complexo de criação e de invenção e não de mera imitação.

Tauveron (1999) aponta caminhos sobre como construir uma postura de autor, afirmando que não há uma transferência direta da leitura literária para a escrita literária. Leitura e escrita não são atividades simétricas, e construir com as crianças uma postura de autor é uma operação mais complexa que construir uma postura de leitor. Tornar-se autor não é simplesmente criar seu próprio texto utilizando os meios técnicos encontrados na leitura de outros textos; também não é simplesmente escrever pensando no leitor, mas construir uma imagem de si mesmo no seu discurso para exercer uma influência sobre seu interlocutor.

Para Tauveron (2002-2003, p. 204), os alunos colocados em situação de produção de texto literário desenvolvem uma intenção artística e a capacidade de pensar na escrita como uma atividade de concepção deliberada de problemas de compreensão e de interpretação para o leitor. Autor é aquele que estimula a construção de caminhos, investiga pistas não exploradas, é sensível à beleza das palavras. O objetivo é transformar simultaneamente a relação do aluno com seu texto e a relação do aluno com seu leitor. De escritor, o aluno se transforma em autor, mestre dos efeitos que cria no texto, com histórias concebidas como áreas de exploração aberta.

Tauveron e Seve $(2005$, p. 24) consideram a escrita literária não como um fim em si, mas como o terreno ideal para ensinar os alunos a construir uma imagem de leitor. Escrever e ler são atos conexos e que necessitam de um esforço conjugado de dois agentes distintos, o autor e o leitor. $\mathrm{O}$ artista deve confiar a outro a realização da tarefa que ele começou. Escrever, portanto, é apelar ao leitor para que ele faça passar à existência objetiva o que o autor começou a revelar por meio da linguagem. Assim, leitura e escrita literária são interdependentes. As proposições práticas 
para o trabalho com os alunos em situação de escrita devem levá-los a se conscientizar de seu próprio funcionamento mental ao interpretarem um texto literário, tornando-os capazes, a partir disso, de provocar nos seus leitores potenciais um trabalho interpretativo ou uma cooperação similar.

Para Tauveron e Seve (2005, p. 28-30), a escrita literária é um lugar de integração tanto de uma cultura dos livros quanto de uma cultura do mundo. Dos livros, porque toda ficção é tirada dos sedimentos deixados pelas histórias ouvidas/lidas anteriormente, e do mundo, porque o autor alimenta seu universo ficcional passado, presente ou conjectural, conforme ou não ao mundo real, a partir de uma documentação anterior. Na escola, o aluno precisa aprender que o produto narrativo de um autor é sempre uma forma de acumulação e de decomposição de obras anteriores, emprestadas, citadas e remodeladas. Assim, não é repreensível o empréstimo de fórmulas anteriormente encontradas para empregar em suas produções textuais. Trata-se de ensinar os alunos a dominarem o campo discursivo e linguístico e encorajá-los a integrarem suas experiências sociais, sensoriais e sua memória de leitor num texto de ficção.

A concepção de escrita adotada por Tauveron (1996) se apoia numa visão sistêmica do seu ensino, posicionando-se contra a fragmentação, em que se aprende separadamente a escrever um diálogo, a fazer uma descrição, a construir uma intriga, sem que jamais essas aprendizagens sejam colocadas em correlação e integradas na execução de uma atividade de escrita.

Tauveron (1996, p. 194) afirma que não é possível uma imaginação criativa sem técnica, pois a técnica pode servir para acionar o imaginário. A aprendizagem de técnicas da escrita literária é indispensável como condição para o desenvolvimento da liberdade e da autonomia do escritor. Ensinar a escrever os textos pragmaticamente, semanticamente e morfossintaticamente desenvolve nos alunos uma competência de escrita de base. Um escritor tem uma vida interior imaginativa intensa, que lhe permite formar a trama de uma história. Essa vida interior precisa ser disciplinada para passar do estado da fantasia à realidade, e o autor consegue isso utilizando técnicas, como o tratamento do tempo e do espaço ficcional, a adoção de um ponto de vista para o narrador, a busca de plausibilidade e coerência, o trabalho com as palavras para criar um estilo e imagens internas. As técnicas, desse modo, permitem ao aluno-autor organizar esse magma interior, sendo 
indispensáveis para viabilizar a socialização da fantasia e a sua comunicação pública (TAUVERON, 1996, p. 195).

$\mathrm{O}$ aluno se distingue do escritor na medida em que se encontra mais em situação de aplicação de técnicas que em situação de criação de soluções inéditas, mas convém não negligenciar seu poder de iniciativa. Não há dúvida de que é preciso aprender as regras de funcionamento da língua, mas a fonte motivadora para o aluno escrever literatura não está nesse aprendizado, senão nas obras literárias já existentes, no conjunto de obras que ele leu. Assim, como afirma Lecuyer (1992, p. 172), o escrito se organiza na intertextualidade, ou seja, nas relações que ele estabelece com outros escritos. No caso da criança pequena, como essa experiência é ainda restrita, acredita-se que, num primeiro momento, o importante é deixá-la escrever livremente, sem se preocupar com as suas motivações ou com os efeitos de seus passos, para que pouco a pouco a escola a ensine a criar a trama da história, que é a motivação inicial, ou o que Lecuyer chama de fio da meada, para que as crianças comecem a escrever (1992, p. 171) e assim evoluir para explorar as estruturas narrativas, as palavras e presenciar o que Jay (2007, p. 93) chama de intenção artística e estética.

Enfim, dessas reflexões conclui-se que uma criança pode ser um autor e escrever literatura, considerando que isso não é um dom, mas uma prática que pode ser ensinada na escola. Para isso, o começo de tudo é a leitura e a compreensão de que a escrita se trata de um jogo de idas e vindas com a linguagem, com intenção artística e estética, com a imaginação, com a intertextualidade, com um potencial leitor.

\section{ESCREVENDO UMA NARRATIVA NA ESCOLA}

Neste artigo analisaremos dois textos literários, uma narrativa e uma fábula, produzidos nas aulas de Língua Portuguesa por alunos do $4^{\circ}$ ano de uma escola da Rede Municipal de Ensino de Curitiba. Ao mesmo tempo, apresentaremos as estratégias pedagógicas do professor com vistas à formação do aluno-autor.

Este trabalho é parte de uma pesquisa etnográfica realizada em 2009, que gerou mais de 80 horas de observação em uma turma de $4^{\circ}$ ano. As observações ocorreram de forma passiva, não havendo qualquer 
intervenção da pesquisadora. O mais importante para assegurar os princípios da etnografia foi ter conseguido o envolvimento na vida cotidiana da escola por um período prolongado de tempo, de abril a dezembro, observando o que acontecia, escutando o que era dito, fazendo perguntas à professora $\mathrm{e}$ aos alunos e compilando as produções dos alunos.

Durante a pesquisa de campo inúmeros textos foram compilados. A escolha dos textos aqui analisados não se deveu ao gênero abordado, mas ao fato de serem ricos em exemplos tanto do potencial de escrita do aluno-autor quanto das suas limitações. A condução do trabalho pelo professor também pesou favoravelmente na escolha por revelar o papel da escola na formação do aluno-autor.

No dia 13/4/09, a professora distribuiu uma cópia para cada aluno do conto "História de Assombração", de Mário Neme (1965). Pediu que fizessem a leitura silenciosa, seguida de leitura em voz alta pela professora e de discussão coletiva sobre a história. Os alunos demonstraram ter familiaridade com esse gênero literário, dada a desenvoltura com que imediatamente o identificaram como escrito com suspense e analisaram o modo de descrever a história pelo autor, o que tornou o enredo mais interessante, envolvente e capaz de prender a atenção, além de discutirem os indícios do texto capazes de provocar medo. Os alunos colaram no caderno a orientação apresentada na Figura 1.

\section{Figura 1}

Orientação de atividade realizada na aula de Língua Portuguesa do dia 13/4/2009.

- Bem, é claro que, depois de analisarmos todas essas formas de construção de suspense, vamos pedir que você crie a sua história de suspense!

- Dê asas à imaginação... O que acontecerá? Com quem? Pense na história toda primeiro, faça um pequeno roteiro do que irá contar. Depois, vá imaginando os detalhes do espaço, das personagens, das reaçōes e dos sentimentos delas ao viverem os acontecimentos... Escreva todos eles para que seu leitor possa vivê-los também!

\section{Fonte: Fotocópia de caderno de aluno.}

Considerando a importância e a complexidade da compreensão de como construir um texto literário, há muitos autores dedicados a pensar nas estratégias para viabilizá-lo na escola de ensino fundamental, como Foucault et al. (1993), Giasson (2000), Poslaniec e Houyel (2000), Tauveron e Seve (2005), Lagache (2006), Tsimbidy (2008) e Perrin (2010). Embora com algumas nuanças, os autores tratam principalmente dos seguintes aspectos da 
arquitetura dos textos literários: tema, intriga, narrador, ponto de vista, personagem, estrutura, sequência, coerência, verossimilhança, espaço e tempo. Os autores são unânimes em indicar que é preciso primeiramente ensinar os alunos a localizar os indícios nas obras para depois solicitar a criação de indícios em seus próprios textos.

A professora da escola observada forneceu orientações muito úteis para os alunos ao solicitar que, ao criarem a sua narrativa, abordassem alguns dos aspectos da arquitetura dos textos literários indicados pelos autores. Como vemos na Figura 1, o ponto de partida sugerido por ela foi o gênero literário (suspense), seguido do planejamento do texto (roteiro), da definição dos acontecimentos e do detalhamento dos espaços e dos personagens, tudo isso pensado estrategicamente para criar efeitos no leitor. O contexto criado para essa situação de escrita foi bastante motivador para os alunos. $\mathrm{O}$ gênero escolhido os agradou muito. O texto selecionado lhes provocou medo e suspense e as orientações da professora os encorajaram a se sentirem capazes de também provocar medo por meio de sua escrita. Os alunos conseguiram produzir textos interessantes, embora ainda com muitas limitações, o que é compreensível para crianças de apenas 9 anos de idade e que estão se familiarizando com a escrita literária, como pode ser observado na análise do seguinte texto de um dos alunos.

\section{A casa mal-assombrada}

Era uma vez uma casa que ficava dentro do cemitério.

Um dia 6 amigos, sendo 3 meninas e 3 meninos. Eles estavam jogando voley, de repente a bola entrou no cemitério. João o mais velho, disse:

- Ah! E agora são 6:00 da tarde temos que ir embora, pois dizem que 6:30 na casa que há lá dentro, existe um bonequinho chamado Lion e ele mata as pessoas. Amanda e Mariana responderam:

- Que bobagem!

E ele respondeu:

- Então entrem lá e peguem a bola.

Mas pensei agora são 6:10.

- OK, vamos Mari!

E assim elas foram e os outros 4 ficaram. Amanda e Mariana estavam andando quando escutaram um ploc-ploc. Elas ficaram com medo do que poderia ser.

Amanda disse:

- Mari você que tem relógio, que horas são?

Mariana respondeu:

- 6:30, será que é o boneco Lion? 
- Não, que besteira!

- Éh, vamos indo.

Os quatro lá fora estavam preocupados. Lucia e Kaio os mais novos falaram:

- É seis e meia, vamos entrar!

Juca e Vitor falaram:

- Está bom!

Assim que eles estavam lá encontraram elas. Assim que as viram falaram:

- Oi.

- Fiquem quietos!! Disseram as duas. Venham aqui.

Assim que eles chegaram lá elas explicaram:

- Acabamos de escutar passos.

João respondeu:

- Não falei! É o boneco Lion!

Que bobagem! João! Disse Lucia.

- Parem vocês estão me assustando, falou Kaio.

Começou a chover e eles avistaram uma casa, só que no momento nem se lembraram do boneco. Entraram na casa e logo avistaram um boneco ensanguentado, Kaio disse:

- Vamos embora daqui!!

Não, disse Mariana, está chovendo.

Logo após a discussão, os 6 escutaram uma batida de porta, eles se trancaram no quarto.

Eles saíram do quarto e viram que não havia boneco nenhum.

Mas sim um homem comendo um pão e tomando uma taça de vinho tinto.

Eles perguntaram ao homem:

- Você é o tal boneco Lion?

Claro que não! Sou um fazendeiro, mas me chamo Lion.

E porque tu moras aqui?

Bom eu estava chegando, passei por aqui e vi esta casa, me estalei. - Hum.

- Querem pão?

- Não vamos indo.

E assim foram segundos em frente. Chegaram em casa e a mãe perguntou:

- Por que a demora?

- Mãe o João bundão quis assustar a gente.

- Éh João.

- Bem, vou jogar futebol.

- Não vai, antes vai me dizer se é verdade isso.

- Esta mãe é.

- OK, você vai ficar 6 semanas sem jogar futebol.

Vamos retomar os aspectos indicados anteriormente quanto à arquitetura do texto literário, para procurar identificar como o aluno-autor de "A casa mal-assombrada" os trabalha em seu texto. Ao analisá-lo, 
pretendemos refletir sobre as possibilidades de formar o aluno-autor no ambiente escolar. Para imprimir uma dimensão de intencionalidade à atividade de escrita literária, entendemos que a primeira etapa a ser vencida pelo aluno-autor é a definição do gênero narrativo com que vai trabalhar. No caso aqui apresentado, embora o gênero tenha sido proposto pela professora, ele foi bem recebido pelos alunos, uma vez que ela procurou inicialmente familiarizá-los com o gênero suspense, partindo da leitura de um texto para que os alunos tomassem consciência do seu funcionamento e descobrissem os seus mecanismos.

O gênero serviu como uma bússola para guiar o aluno-autor. A partir daí, ele definiu a forma e o tom que desejava adotar, pois, como ressaltam Foucault et al. (1993, p. 12), não se escreve da mesma maneira quando se escolhe um tom trágico, um tom humorístico, um tom impessoal, um tom sarcástico ou um tom lírico, por exemplo.

Uma fragilidade observada refere-se ao fato de parecer que o aluno-autor não planejou minuciosamente seu texto antes de escrever. Essa questão se evidencia, por exemplo, quando os personagens entram na casa e logo avistam um boneco ensanguentado, criando uma situação tensa e de grande suspense que, no entanto, é ignorada na continuidade da narração. Outro exemplo pode ser observado pelo não esclarecimento de por que um fazendeiro se apossaria de uma casa em um cemitério. A impressão provocada é a de que o aluno-autor não possui uma visão de conjunto do que vai escrever e que ele se lança diretamente na história sem refletir sobre o desencadeamento dos acontecimentos e a globalidade de seu texto. A narrativa parte numa direção e encontra dificuldade para manter o curso.

Uma questão considerada muito importante para o aluno-autor refere-se à definição do narrador. No caso do texto em pauta, o narrador se manifesta nas três primeiras frases e reaparece com a frase "Mas pensei agora são 6:10". Predominam no texto os diálogos entre os personagens, que a nosso ver poderiam ser intercalados pela vOz do narrador para orientar, guiar ou provocar o leitor.

Quanto à criação dos personagens, Lagache (2006) afirma que é preciso considerar que eles pertencem a um sistema em que cada um se compreende nas relações com os outros. Na narrativa em pauta, o aluno-autor se perde ao apresentar os personagens. Inicialmente se refere a seis amigos que jogavam vôlei, entretanto apresenta sete crianças: João, Amanda, Mariana, 
Lucia, Kaio, Juca e Vitor. Os três primeiros são os personagens principais, ao redor dos quais se organizam as forças motrizes que permitem ao leitor criar uma representação, uma opinião e estabelecer com eles uma relação de empatia ao longo da narrativa: com o João por ser um personagem desafiador e ardiloso, com Mariana e Amanda por serem duas meninas corajosas e, além destes, com Kaio por ser um menino medroso. Os demais são apresentados sem qualquer detalhamento de suas características.

A mãe, embora seja uma personagem secundária, é a responsável pelo desfecho da narrativa. O aluno-autor se perde também ao introduzir a personagem materna, pois afirma que, após as crianças chegarem em casa, uma delas denuncia João à mãe, que o repreende. O problema é o denunciante tratar a personagem como mãe, sendo, supostamente irmão de João, o que não faz sentido, uma vez que as crianças foram apresentadas pelo narrador como amigas.

Outro personagem introduzido trata-se do fazendeiro Lion, que tem um papel secundário e pouco expressivo, o que representa um desperdício da oportunidade de contribuir para o suspense da narrativa. Nesse caso, o aluno-autor poderia ser orientado quanto ao que dizem Foucault et al. (1993) sobre ser indispensável fazer um personagem existir aos olhos do leitor, de modo a tentar surpreendê-lo e contribuir com o prazer de ler. Deveria, também, ser orientado para criar uma coerência entre os diversos elementos que caracterizam um personagem: suas emoções, sentimentos dominantes, sensações mais frequentes, seus gostos etc. Giasson (2000) sugere que o professor solicite aos alunos a identificação, nos livros que leram, dos parágrafos em que são descritos os personagem e o que faz o autor para torná-los "vivos": os diálogos, os detalhes, o humor ou os elementos intrigantes. Sugere a observação da maneira como os personagens emergem, os acontecimentos da história e a maneira como eles permitem ao personagem evoluir e mudar, as razões que fazem com que alguns pareçam vivos enquanto outros são opacos, as razões pelas quais um personagem parece verossímil (é por causa do que ele diz, do que ele faz? É por causa do que os outros pensam dele, da maneira como eles reagem a ele ou pelo que lhe dizem?), ou seja, observar como o autor consegue criar um retrato vivo de um personagem e como imputa credibilidade a ele.

Para Poslaniec e Houyel (2000), é fundamental que o professor construa com os alunos o entendimento de que o personagem não é uma 
pessoa, mas que deve dar a ilusão de ser, o que pode ser conseguido, por exemplo, pela descrição da classe social, das características de uma época, das vestimentas, da linguagem utilizada, do gestual, da cultura, da idade, do modo de vida etc. A partir dessas descrições, o leitor empresta ao personagem as emoções, as particularidades físicas, as referências, que não estão descritas na narrativa. O leitor constrói uma imagem mental do personagem, que vai se modificando na medida em que novas informações se acumulam.

Para Tauveron e Seve (2005), o professor precisa dialogar com o aluno-autor de forma que ele possa justificar as suas escolhas: no caso de decidir por não descrever os personagens, é preciso saber o motivo, se porque eles não são importantes na intriga ou porque tal é a regra do gênero escolhido, ou porque ele quer guardar o mistério ou enganar o leitor com falsas pistas. Caso ele escolha descrever, as autoras lembram que ele precisa decidir como vai criar as condições que permitam ao leitor acreditar na existência do personagem, como vai provocar no leitor simpatia ou antipatia pela figura criada, como vai permitir ao leitor antecipar o comportamento do personagem na ação e como vai dividir os detalhes ao longo do texto.

Outra questão importante a guiar o aluno-autor refere-se ao estabelecimento da estrutura, que envolve a intriga e a tensão de sua narrativa. A tensão deve ser apresentada ao longo da história, e a intriga completa não é conhecida antes do fim. O aluno-autor tem que aprender a dosar os altos e baixos, de maneira a estimular o leitor a continuar a ler. No texto do aluno-autor aqui analisado, a tensão perpassa toda a narrativa. No início, ela se estabelece com a bola entrando no cemitério, seguida da decisão das meninas que, mesmo avisadas dos perigos, resolvem buscá-la. A tensão se mantém com o controle do horário, com os barulhos estranhos e ao avistarem um boneco ensanguentado e um homem estranho, sendo que a solução para a intriga vem ao final, quando a mãe repreende o João por ter assustado as crianças.

Para incrementar essa estrutura, o aluno-autor precisa ser orientado a refletir sobre diferentes estruturas encontradas nas obras da literatura infantil e ser questionado sobre a estrutura das suas produções, procedimento que pode ser conduzido com perguntas, como as sugeridas por Giasson (2000): Como a história começa? Com um acontecimento? Qual é o elemento-chave que conduz ao mais forte momento de tensão da história? Como o autor 
criou a tensão e como ele a resolveu? Qual a tensão ao redor da qual se constitui a história e os acontecimentos relacionados a ela?

Para criar estruturas mais elaboradas, Giasson (2000) sugere, ainda, ensinar o aluno-autor a adotar procedimentos literários como os indícios (sinais, vestígios) e os subentendidos (perceber o que não estava exposto ou bem explicado). No caso dos indícios, trata-se de, primeiramente, refletir sobre como os autores disseminam os indícios em seus textos e depois em auxiliar os alunos a pulverizar seus textos com indícios que levem o leitor a antecipar os acontecimentos da história sem romper o suspense.

Quanto aos subentendidos, inicialmente a intervenção consiste em levar os alunos a identificarem as reticências ou as questões em aberto intencionalmente deixadas pelo autor, para depois também inclú-las em suas criações. No texto analisado, o leitor pode inferir, a partir do indício deixado pelo aluno-autor, que os personagens vão vivenciar alguma dificuldade, pois começa a chover e eles estão dentro do cemitério. Um subentendido pode ser percebido com a aparição do fazendeiro Lion, que, na imaginação das crianças, era um personagem maldoso, mas demonstrou ser uma pessoa gentil.

Uma narrativa supõe uma sucessão de acontecimentos e é composta de um esquema que funciona como uma espécie de matriz a ser enriquecida. Para compreender o funcionamento desse esquema, Tsimbidy (2008) se refere a três sequências: narrativa (sucessão de acontecimentos organizados em função de uma lógica de construção do enredo); descritiva (enumeração dos atributos de algo ou alguém) e dialogal (colocação em cena das palavras pronunciadas por diferentes interlocutores). Predomina no texto do alunoautor a sequência dialogal, um bom recurso para fazer acreditar na existência dos personagens, criar um efeito de realidade - reduzindo a distância entre o leitor e os personagens e contribuindo para dar um ritmo ao texto -, dar referências espácio-temporais, revelar características, descrever as ações dos personagens, introduzir novos atores e fazer evoluir a intriga ou, ao contrário, desacelerá-la e manter o suspense.

Um item não solicitado pela professora, mas muito importante na construção da arquitetura de um texto literário, é a verossimilhança. Foucault et al. (1993) sugerem três técnicas para provocar o efeito da verossimilhança. A primeira delas consiste em evitar as contradições entre os fatos relatados e em multiplicar os elementos que confirmam 
que um determinado fato "realmente" ocorreu. A segunda trata-se de, no lugar de a criança apresentar resumidamente um acontecimento, fazê-lo detalhadamente e em função de sua própria experiência. A terceira técnica consiste em recorrer à documentação (mapas, cartas etc.). No caso do texto analisado, o aluno-autor poderia ter tornado seu texto mais verossímil, por exemplo, descrevendo detalhadamente o desespero das crianças ao verem a trajetória percorrida pela bola até entrar no cemitério; introduzindo uma discussão entre as meninas sobre os perigos de entrarem às $18 \mathrm{~h} 30$ num cemitério ou uma discussão entre aqueles que inicialmente não quiseram entrar no cemitério e resolveram fazê-lo mais tarde; descrevendo uma cena de susto no encontro das meninas com as demais crianças dentro do cemitério; descrevendo uma imagem de algo que se parecesse com o boneco ensanguentado supostamente visto pelas crianças, fato que não se confirmou; ou, ainda, descrevendo o trajeto das crianças no escuro ao voltarem para casa. A ficção bem apresentada, bem organizada e envolvente tem a capacidade de ajudar o leitor a efetivamente se envolver com a leitura.

Um item que deve ajudar a criar um efeito de realidade num texto literário e pode situar o leitor num mundo conhecido ou num universo fantástico é a especificação do âmbito espácio-temporal, que remete ao lugar e à época em que se desenvolve a ação. Poslaniec e Houyel (2000) afirmam que o espaço é uma noção complexa, que pode ser apresentada longamente ou simplesmente sugerida, cabendo ao leitor imaginar o deslocamento dos personagens e seus itinerários. No texto analisado, a escolha de um ambiente como um cemitério dispensa detalhamentos, pois a palavra imediatamente remete o leitor a um lugar de enfrentamento da morte, de perda, de tristeza e cercado de simbolismos quanto ao sobrenatural. O aluno-autor descreve o deslocamento dos personagens ao andarem pelo cemitério, ao mesmo tempo em que escutam barulhos, e também cita a fuga assustada dos personagens para se esconderem num quarto. Essas descrições auxiliam a criar a tensão e a atmosfera de suspense. O espaço ficcional do texto analisado é definido na primeira frase ("Era uma vez uma casa que ficava dentro do cemitério") e o âmbito temporal é definido com a indicação de $6 \mathrm{~h}$ da tarde como o momento em que começa a se desenvolver a ação. A descrição do espaço, quando acompanhada de detalhes do tempo, ajuda a criar o clima da narrativa: "A bola entra no cemitério e são 6h da tarde...". A inclusão do horário torna a narrativa mais real e cria uma expectativa de suspense, 
em função do entardecer que se inicia e dentro de um ambiente como um cemitério. É possível perceber como os personagens ou a atmosfera da história são influenciados pelo registro do passar da hora.

A experiência com a escrita literária desenvolvida nesta escola, embora ainda passível de incremento, se prestou como um instrumento para os alunos pensarem, se comunicarem, despertarem a emoção estética, desenvolverem o imaginário, se tornarem autônomos e capazes de elaborar sua própria reflexão, tendo confiança em seu pensamento e seu julgamento.

\section{ESCREVENDO UMA FÁBULA NA ESCOLA}

A segunda produção realizada na escola observada trata-se de uma fábula. Uma das iniciativas muito positivas das professoras foi a realização do planejamento integrado, envolvendo a professora de Língua Portuguesa, a de Literatura e a de Informática.

Para se familiarizarem com esse gênero literário, durante as aulas de Informática os alunos pesquisaram na internet diferentes fábulas, para conhecerem suas características e autores. Nas aulas de Literatura tiveram acesso a inúmeros livros de fábulas e bastante tempo para lê-los. A escrita de fábulas foi desenvolvida nas aulas de Língua Portuguesa, ocasiões em que ilustraram as suas produções e montaram livros de fábulas para empréstimo a crianças de outras turmas. Além disso, tiveram a oportunidade de inscrever suas produções em um concurso de fábulas promovido pela Secretaria Municipal de Educação, que premiou uma das alunas da turma. A inscrição foi orientada pela professora de Informática, pois os alunos tiveram de digitar suas fábulas num portal da Rede Municipal de Ensino (RME), que permitia o acesso às fábulas dos alunos por todas as crianças da rede.

O conjunto das atividades sobre as fábulas acabou gerando um grande interesse dos alunos, que, ao serem entrevistados pela pesquisadora, demonstraram muita segurança para falar sobre as características das fábulas e sobre como escrevê-las:

Pesquisadora - Quais são as características da fábula?

JC - Tem que ter o diálogo e uma imaginação grande, tem que fingir que os animais falam.

Pesquisadora - E no final?

JC - Tem que ter a moral da história. 
MR - O poeta usa rimas como estratégia. A fábula tem uma coisa pra passar.

AC - Na fábula os animais eles agem como humanos.

RV - Na fábula fazem os animais falarem e isso dá mais emoção à história.

Pesquisadora - E o fabulista? Você também já é um fabulista que eu já vi você escrever fábula, né? Quais são as estratégias do fabulista?

LU - Ah é... já tem que saber uma moral, porque é tipo assim você faz uma história, uma fábula e depois não sabe o que colocar na moral, você vai ter que apagar tudo, então você já tem que pensar na história e na moral, porque daí já fica melhor para você.

Considerando que nosso objetivo é analisar a escrita literária e que a produção escrita se deu nas aulas de Língua Portuguesa, vamos enfatizar as observações relativas a essas aulas, ocorridas nos dias 4, 6 e 27/5/09. Nessas ocasiões, eles relembraram as características das fábulas (narrativas em que os animais têm comportamento humano e falam, sendo ressaltadas as características de cada um e associadas ao comportamento humano - por exemplo, a esperteza da raposa, a rapidez da lebre, a beleza do pavão, a força e coragem do leão, a ingenuidade do burro, o ardil da cobra, a lerdeza da tartaruga...); contaram as fábulas que conheciam; ouviram a narrativa pela professora das fábulas "O leão e o camundongo", "A raposa e a cegonha", "O gato e o raposo" e a "A cigarra e a formiga"; e recordaram os autores La Fontaine, Esopo e Monteiro Lobato. Os alunos também colaram no caderno as orientações apresentadas na Figura 2.

Observa-se que as orientações coladas nos cadernos contêm elementos essenciais para a formação do aluno-autor. Os alunos começam se familiarizando com as características do gênero literário fábula; são motivados a elaborar rascunhos e reescrever o texto como partes integrantes e indispensáveis a quem se propõe a escrever literatura; e são estimulados a escrever considerando a arquitetura de uma fábula: personagens animais que vão viver um enredo como se fossem humanos, culminando com a resolução do problema explicitado numa moral ou provérbio, além de orientações quanto à estrutura da fábula, como a necessidade da criação de um título, dos diálogos destacados entre aspas e da utilização de uma linguagem concisa. 


\section{Figura 2}

\section{Texto colado no caderno: atividade realizada na aula de Língua Portuguesa do dia 4/5/2009. $\frac{\text { CONHECENDO UM POUCO MAIS SOBRE }}{\text { ASFABULAS }}$}

Há muitos e multos anos, o hamem comecou a contar historias de todos os tipos. Umas que explicavam as colsas da natureza, outras que talavam sobre suas viagens, sua vida, seus desejos... Umas com fadas e seres mágicos, outras com animais. plantas ou objetos com qualidades humanas.

As fábulas constituem um desses tipos de história de que estamos falando e săo contadas há mais ou menos 2.800 anos. Geralmente, elas apresentam uma cena vivida por animais, plantas ou objetos que falam e agem como se fossem gente.

Elas săo contadas ou escritas para dar conselhos, para alertar sobre algo que pode acontecer na vida real, para transmitir algum ensinamento, para fazer alguma critica, etc. Por isso, muitas vezes, no finalzinho das fábulas, isto é, quando a história acaba, aparece uma frase destacada, que costumamos chamar de moral da história.

A maioria dessas histórias trata de certas atitudes humanas, como a disputa entre fortes e fracos, a esperteza de alguns, a ganância, a gratidăo, o ser bondoso.... Esses săo alguns dos temas das fábulas.

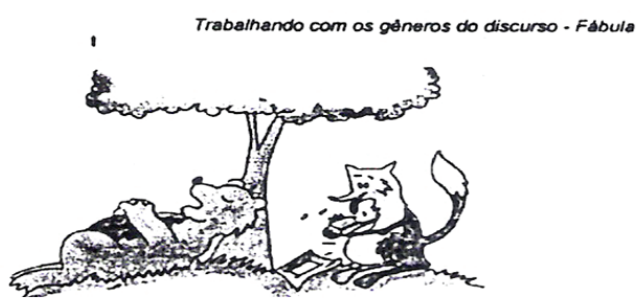

IMPORTANTE

A partir de todos os conhecimentos construidos até aqui, não se esqueça de que nenhum escritor, ao escrever, começa e termina uma história de uma vez só. Ele escreve um pedaço... tem outra idéia, volta. modifica e assim faz, até achar que a história ficou pronta.

Ah, o rascunho é muito importante, pois é nele que você vai "lapidar" suas idéias: apagar, anotar, rabiscar, grifar trechos que quer manter ou modificar, enfim, fazer tudo aquilo que julgar importante para melhorar seu texto. fábula:

Seguem alguns lembretes para escrever o texto no estilo de uma

"Pensar nas personagens que representam melhor o acontecimento que será enfocado e que poderia ter sido vivido por seres humanos:

" Só descrever o lugar em que acontece a história ou as personagens se isso for necessário para o leitor compreender a fábula.

* Criar diálogos, marcando as falas das personagens com aspas ou parágrafo e travessõo.

- Evitar a repetição de palavras, principalmente para se referir ds personagens.

* Lembrar que a resolução do problema deve combinar com a sua intençăo de contar a fábula e com a moral da história.

" Escrever a moral da história de modo explicativo ou utilizando um provérbio.

- Criar um título para a fábula.

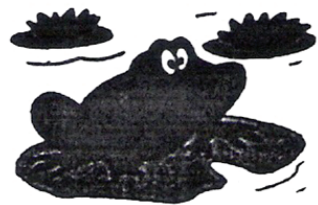

Fonte: fotocópia de caderno de aluno. 
A partir dessas orientações, os alunos escreveram suas fábulas tanto em duplas quanto individualmente, e, para auxiliar as crianças a criarem a moral, a professora escreveu no quadro alguns ditados populares: "Devagar se vai ao longe", "Mais vale um pássaro na mão do que dois voando", "Quem tudo quer tudo perde", "A mentira tem perna curta". Durante a escrita, a professora passava pelas carteiras e provocava as crianças para que pensassem sobre o que estavam escrevendo, sobre os cuidados com a ortografia, sobre os personagens e suas características, sobre o enredo e sobre a importância de criarem diálogos entre os animais. Ela não dava respostas prontas, apenas provocava a reflexão dos alunos. Lebrun (1996) ressalta esse papel do professor como moderador do trabalho: supervisor, para se certificar da frequência de participação dos alunos, e estimulador dos mais fracos. Cabe ao professor estimular os alunos para que percebam os pontos de resistência dos seus textos e suas ambiguidades, para que desenvolvam julgamentos estéticos e éticos sobre os atos e as motivações dos personagens, para que estabeleçam relações com outros textos, com suas experiências pessoais e com a atualidade e para que exprimam emoções e pontos de vista subjetivos relativamente à ação e à escrita (sensibilidade às metáforas, aos jogos de linguagem etc.). A professora foi muito bem-sucedida ao sugerir que lessem suas fábulas para todo o grupo ouvir, oportunizando que experimentassem os efeitos provocados nos seus "leitores", de modo que, quando percebiam que não alcançavam seus objetivos, reescreviam o texto.

Considerando a predominância da produção de texto individual nas escolas, ressaltamos mais esse diferencial proposto pela professora, que foi o trabalho em duplas. Nesse momento, eles tiveram a oportunidade de discutir longamente, antes de começarem a escrever, como seriam seus personagens, o que se passaria com cada um deles e como seriam o desfecho e a moral. A riqueza do debate provocado pela estratégia do trabalho em duplas permitiu que cada um falasse, emitisse sua opinião, externasse detalhadamente suas ideias e negociasse como seriam os personagens. Quando passavam a escrever a fábula, continuavam negociando sobre as escolhas sintáticas, léxicas etc. Lebrun (1996, p. 77) ressalta que, na discussão em pequeno grupo, o aluno, sobretudo o mais tímido, pode exprimir frequentemente seu ponto de vista, refinar suas hipóteses, emitir suas dúvidas e solicitar esclarecimentos, porque a palavra se alterna mais entre os membros do grupo. 
Pode ser muito estimulante para os alunos a alternância entre os momentos de trabalho individual e coletivo, em pequenos ou grandes grupos. As oportunidades de discussão em grupo habilitam o aluno, segundo Lebrun (1996, p. 77), a escutar a opinião dos outros, a desenvolver uma argumentação por confrontação de diferentes pontos de vista, a respeitar a sua vez de falar e a ativar e estruturar saberes anteriores. Em geral, a discussão favorece a emissão de hipóteses, promovendo as atividades cognitivas, tais como a expressão de opinião, a argumentação e a formulação ou clarificação de um problema.

Os alunos estavam muito seguros e motivados para se lançar na escrita, como se pode observar em uma das fábulas produzidas e apresentada na Figura 3.

A desenvoltura com que esse aluno-autor criou sua fábula pode ser atribuída ao conjunto de atividades desenvolvidas, que propiciaram a imersão nesse gênero literário e lhe permitiram se sentir à vontade, inclusive de surpreender seus leitores com situações de humor, raras nos textos dos alunos e consideradas difíceis de produzir. A decisão do aluno-autor de iniciar determinando de forma bem precisa o tempo ("Num dia maravilhoso de sol") o ajudou a introduzir melhor o leitor na atmosfera de felicidade e encontros da narrativa, cuja sensação se faz presente em todo o texto. $\mathrm{O}$ provérbio Cada panela tem sua tampa, além do humor, provoca a reflexão sobre a existência da felicidade nos encontros amorosos, ou para a possibilidade de existência de duas metades que se completam, ou para a possibilidade de um grande amor.

Há inúmeras vantagens em estimular os alunos para que escrevam literatura, como as apontadas por Colomer (2007): eles experimentam o prazer de inventar mundos de ficção; aprendem a dominar a expressão do discurso escrito; compreendem e apreciam a estrutura e a força expressiva dos textos; criam ideias originais, argumentos e tramas; produzem efeitos sobre o leitor; dominam as potencialidades de abstração da linguagem; têm acesso ao prazer estético e desenvolvem o imaginário. $\mathrm{Na}$ turma pesquisada, foi possível perceber que as crianças, ao longo do ano, foram se familiarizando com a escrita literária e sendo estimuladas para encontrar prazer em realizar tais atividades. 
199

Figura 3

Produção de aluno: atividade realizada na aula de Língua Portuguesa do dia 4/5/2009.

Drmacacosea zebra

Num dia maravilhoso de sd, quando o macace estarre comendo sua banana ouvie um grito de felicidade bem longe, que parecia da zebra.

Depois de alguns minutos o macarco viu uma sombra passando bem rapido, saindo da poira, era a zebra: gre?

- Porque vocé estí́ tão ale-

- Prque unestor ramoran do $\theta$ ze brave.

- Gueméeste rapaz?

- As! En acho que vocí nãa conkes ce, ele éorri de Zebrópolis.

No outro dic era o macaco que estarra saltitando de galho em galho enquanto a zelra e zebrä estavam trocando beiginhos, er foram lá folar com eles.

A zebra falou:

- Salica que vocéia nomotiar! Igual a mime zebrava.

Moral:

Cada panela tem sua tompan

Fonte: fotocópia de caderno de aluno.

Educação em Revista | Belo Horizonte | v. 29 | n. 01 | p. 179-203| mar. 2013 


\section{CONSIDERACְÕES FINAIS}

Neste artigo, analisamos as estratégias pedagógicas utilizadas com uma turma de $4^{\circ}$ ano do ensino fundamental, de forma que o aluno se colocasse na condição de autor. O ponto de partida das experiências analisadas foi a aproximação dos alunos com determinados textos de referência do gênero literário a ser trabalhado e a análise dos recursos utilizados pelos autores, como inspiração para o aluno encontrar seus próprios caminhos criativos. A professora forneceu orientações sobre as técnicas da escrita literária, que foram indispensáveis no auxílio do desenvolvimento da imaginação dos alunos. É importante frisar que, embora esses aspectos estivessem presentes, eles careceram de um refinamento, principalmente quanto ao aprofundamento das análises dos textos para a identificação das estratégias dos autores para disseminar indícios.

Analisamos dois textos de alunos, nos quais identificamos algumas fragilidades, como um narrador que nem sempre guia o leitor, personagens que não parecem reais aos olhos de quem lê, intrigas que nem sempre surpreendem o leitor e o mantêm atento até o final da narrativa, definições no âmbito espaço-temporal que nem sempre são eficazes para remeter o leitor ao lugar e à época em que se desenvolve a ação e apenas precariamente provocam a sensação de verossimilhança. Evidenciou-se que, ao escreverem, os alunos ainda não dominavam totalmente, ou não demonstravam ter plena consciência, da arquitetura dos textos literários e da necessidade de planejar detalhadamente o texto antes de escrevê-lo. Assim, conclui-se ser imprescindível o professor auxiliar os alunos a perceberem as fragilidades dos seus textos quando ignoram o respeito à sua arquitetura, bem como permanentemente instigar o aluno para que justifique suas opções de escrita e, consequentemente, se conscientize das suas escolhas.

Não obstante as dificuldades e limitações da escola apontadas para a formação do aluno-autor destacamos algumas iniciativas ocorridas durante as observações que, a nosso ver, contribuíram para superá-las: o planejamento integrado dos professores; a crença de que as crianças, mesmo com pouca idade, desde que bem estimuladas, podem escrever textos literários; a gradativa conscientização dos alunos da necessidade de utilizar estratégias, como fazem os escritores, para facilitar o aprimoramento da sua escrita; a disponibilidade permanente da professora para atender os alunos, e de forma afetuosa; a leitura em voz alta empolgada; o empréstimo de livros para ler em casa; o estímulo permanente à autonomia dos alunos, para que 
construam caminhos próprios de enfrentamento das suas dificuldades; e a possibilidade de testar os efeitos do seu texto com a leitura para os colegas da turma.

As atividades sugeridas propiciaram a aproximação da leitura, da escrita e da aprendizagem do conteúdo literário e se diferenciaram pelo fato de os alunos encontrarem uma finalidade e um sentido para a sua escrita. O domínio das técnicas literárias visou esclarecer a possibilidade de facilitar a escrita pelo aluno-autor e motivá-lo a escrever com prazer e maior autonomia. Escrever deixa de ser uma atividade realizada porque a professora julga importante, para ser um desejo do aluno de externar as suas ideias, de se comunicar com seu leitor, pelo prazer de desenvolver o seu imaginário, transformando-se num verdadeiro prazer intelectual.

É possível afirmar que as proposições práticas para o trabalho com os alunos em situação de escrita literária foram utilizadas na escola pesquisada como meio de os alunos se reconhecerem como autores de literatura.

Constata-se serem inegáveis as inúmeras determinações que afetam negativamente a vida escolar, ao mesmo tempo em que, como espaço de resistência, manifestam-se práticas criativas com o letramento literário, não mais apenas como possibilidade futura, mas como realidade concreta. 


\section{REFERÊNCIAS}

COLOMER, T. Andar entre livros: a leitura literária na escola. São Paulo: Global, 2007.

DESVIGNES, M.-J. La littérature à la porte des enfants: Enjeux des ateliers d'écriture dès l'école primaire. Paris: L'Harmattan, 2000.

DUFAIS, J.-L.; GEMENNE, L.; LEDUR, D. Pour une lecture littéraire: Histoires, théories, pistes pour la classe. 2. ed. Bruxelles: De Boeck \& Larcier S.A., 2005.

FOUCAULT, J. et al. Les coulisses de l'écriture: faire écrire les jeunes et les publier. Amiens: Éditions Corps Puce, 1993.

GIASSON, J. Les textes littéraires à l'école. Boucherville: G. Morin, 2000.

GONZÁLES, A. M. M. La construction de la posture d'auteur dans les projets littéraires: écrire de la littérature pour apprendre la littérature. Repères, Lyon, n. 40, p. 201-225, 2009. GROMER, B.; SCHEIDHAUER, M.-L. Le travail d'écriture littéraire. In: DÉPARTEMENT «Didactiques des Disciplines» Unité Français le Groupe EVA. Paris: Hachette Éducation, 1996. p. 30-52.

JAY, B. Il faut un coeur pour un homme comme pour une histoire. De L'observation du sujet scripteur à l'école élémentaire. In: BISHOP, M.-F.; ROUXEL, A. (Coords.). Sujet lecteur, sujet scripteur, quels enjeux pour la didactique? In: Revue le Français Aujourd'hui. Paris: A. Colin, 2007. p. 83-93.

LAGACHE, F. La littérature de jeunesse: la connaître, la comprendre, l'enseigner. Paris: Éditions Belin, 2006.

LEBRUN, M. Expérience esthétique et développement cognitif par la «réponse» à la littérature de jeunesse. Repères, Lyon, n. 13, p. 69-84, 1996.

LECUYER, C. Écrire et lire à l'école élémentaire. In: ORIOL-BOYER, C. (Ed.). Ateliers d'écriture. Grenoble: L'Atelier du Texte, 1992. p. 169-180.

NEME, M. História de assombração. In: CAMPOS, P. M. (Org.). Antologia brasileira de bumorismo. Rio de Janeiro: Editora do Autor, 1965.

PERRIN, A. Quelle place pour la littérature à l'école? Paris: Retz, 2010.

POSLANIEC, C. Vous avez dit "littérature"? Paris: Hachette, 2002a.

POSLANIEC, C. (Ed.). Réception de la litterature de jeunesse par les jeunes. Paris: INRP - Institut National de Recherche Pédagogique, 2002b.

POSLANIEC, C.; HOUYEL, C. Activités de lecture à partir de la littérature de jeunesse. Paris: Hachette éducation, 2000.

TAUVERON, C. Des «pratiques d'évaluation» aux «pratiques de révision»: quelle place pour l'écriture littéraire. Repères, Lyon, n. 13, p. 191-210, 1996.

TAUVERON, C. Comprendre et interpréter le littéraire à l'école: du texte réticent au texte proliférant. REPÈRES - recherches en didactique du français langue maternelle, Lyon, n. 19, p. 9-38, 1999.

TAUVERON, C. L'écriture littéraire: une relation dialectique entre intention artistique et attention esthétique. Repères, Lyon, n. 26-27, p. 203-215, 2002-2003.

TAUVERON, C.; SEVE, P. Vers une écriture littéraire ou comment construire une posture d'auteur à l'école de la GS au CM. Paris: Hatier, 2005.

TSIMBIDY, M. Enseigner la littérature de jeunesse. Toulouse: Presses Universitaires du Mirail, 2008. 


\section{NOTAS}

${ }^{1}$ As traduções das obras estrangeiras foram realizadas livremente pelas autoras.

Recebido: 03/07/2012 Aprovado: 28/12/2012

Contato: Universidade Federal do Paraná Setor de Educação Departamento de Teoria e Prática de Ensino Rua General Carneiro, $460,5^{\circ}$ andar

CEP $80060-150$ Curitiba, PR Brasil 